О. В. Архіпова

\title{
ЗАСОБИ МОВНОГО ВИРАЖЕННЯ КОНЦЕПТУ «ЧОЛОВІК» (ЗА РОМАНОМ В. ШКЛЯРА «ЗАЛИШЕНЕЦЬ»)
}

Архіпова О. В. Засоби мовного вираження концепту «чоловік» (за романом В. Шкляра «Залишенець»).

У статті висвітлено розвиток когнітивної лінгвістики, лінгвоконцептології, розкрито термін «концепт», концепт «чоловік», визначено основні концептуальні аспекти і вербалізатори цього концепту.

Ключові слова: вербалізатори, концепт, концептуальний аспект, лінгвоконцептологія.

Архипова Е. В. Средства языкового выражения концепта «мужчина» (по роману В. Шкляра «Залишенец»).

В статье описано развитие когнитивной лингвистики, лингвоконцептологии, раскрыто термин «концепт», концепт «мужчина», определены основные концептуальные аспекты и вербализаторы этого концепта.

Ключевые слова: вербализаторы, концепт, концептуальный аспект, лингвоконцептология. 
Archipova H. V. Means of linguistic expression of the concept of «man» (the novel V. Shklyara «Zalishenets»).

The paper describes the development of cognitive linguistics, lingvokontseptologii, revealed the term «concept», the concept of «man», the basic conceptual aspects and verbalizatory this concept.

Key words: verbalizatory, concept, conceptual aspect, lingvokontseptologiya.

Характерною рисою мовознавства помежів'я XX-XXI ст. $\epsilon$ виникнення й розвиток когнітивної лінгвістики, колом інтересів якої $€$ дослідження теорії інформації і способів іiі мовної реалізації.

Дослідження когнітологів спрямовані на експлікацію концептів, які утворюють концептуальну систему (концептуальну картину світу), що зберігає знання, досвід людської діяльності й результати процесів пізнання людиною світу. Когнітивна лінгвістика в такому розумінні $€$ наукою про закономірності організації і функціонування ментальномовного інформаційного простору [1, с. 9].

В Україні та Росії когнітивні дослідження набули поширення тому, що вони вивчають теми, які завжди хвилювали вітчизняних мовознавців: мова і мислення, функції мови, значення мови для людини і людини для мови.

Початком когнітивних досліджень стали праці нейрофізіологів, лікарів, психологів (П. Брока, К. Верніке, І. Сеченова, В. Бехтєрєва, I. Павлова тощо). На грунті нейрофізіології виникла нейролінгвістика (Л. Виготський, А. Лурія). Стало зрозумілим, що різні відділи головного мозку людини відповідають за різні види мовної діяльності.

На межі XX-XXI ст. у лінгвістиці та суміжних із нею науках активізувались поняття, котрі стали наскрізними для багатьох молодих дисциплін (антропоцентричної та когнітивної лінгвістики, глибинної і ситуаційної семантики, дискурсознавства, лінгвокультурології, етнопсихолінгвістики тощо). Одним із них є термін «концепт», який останнім часом активно використовують лінгвісти, оскільки він $є$ більш складною структурою порівняно з лексичним значенням слова, включає в себе невербальну інформацію, характеризується міждисциплінарною належністю і знаходиться на перетині кількох наукових галузей, чим i привертає увагу вчених - представників соціальних комунікацій, культурології, психології, психолінгвістики, філософії [6].

Концепти як ментальні утворення активно вивчають, але до сьогодні не має визначення цього терміну, яке б підтримували всі науковці. Так, на початку 90-х років XX ст. у російській лінгвістичній науці в конкурентній 
боротьбі зійшлися терміни «концепт» (Н. Арутюнова, Д. Лихачов, Ю. Степанов, С. Ляпін та ін.), «лінгвокультурема» (В. Воробйов), «логоепістема» (К. Костомаров, Н. Бурвікова), проте сьогодні найбільш уживаним $\epsilon$ термін «концепт», який широко застосовують у різних наукових дисциплінах, що $є$ причиною його багатозначності. Іноді його вживають як синонім «поняття», не зважаючи на те, що «концепт» $\epsilon$ ширшим за «поняття». Він наближений до ментального світу людини, тобто до культури й історії, тому має специфічний характер.

За словами Ю. Степанова, концепти є культурною спадщиною у свідомості народу, його духовною культурою. Саме колективна свідомість зберігає концепти, які існують постійно або дуже довгий час [8, с. 64].

Лінгвоконцептологія як лінгвістична дисципліна, що займається вивченням вербалізованих концептів - одна 3 молодих галузей мовознавства. ІІї формування $є$ прикметною ознакою лінгвістики XXI ст.

Концепт існує в слові, саме тому він $є$ «концентрацією змісту», презентує не лише поняття, назване словом, але й емоційні елементи, оцінки, асоціації, образи, що характерні для певної культури. Концепти утворюють власні «концептуалізовані предметні галузі» [8, с. 68], тому в тексті вони $є$ редукованими позначеннями прототипових ситуацій, або тем різного статусу.

Існують дві найбільш чітко виражені теорії виникнення й природи концептів: теорія вроджених концептів і теорія поступового набуття людиною концептів і подальшого їх розвитку [7, с. 25].

Ознаки концепту визначають через сукупність лінгвістичних та екстралінгвістичних чинників. Оптимальний доступ для вивчення й опису природи концепту забезпечує мова, мовне вираження концепту відбувається через слово, яке отримує статус назви концепту мовного знака, що передає зміст найбільш повно та адекватно.

С. Воркачов зауважує, що для повноцінного семантичного опису лінгвокультурного концепту потрібно виділити три його складники: понятійну частину, яка містить ознаки й дефініції, образну (фіксує когнітивні метафори, що утримують концепт у мовній свідомості) i значеннєву (визначає місце концепту в лексикограматичній системі певної мови, етимологічні та асоціативні характеристики цього імені) [3, с. 80].

Інтерпретаційне поле окремого концепту становить концептосфера. Це зумовлено природою поля, адже головною властивістю концептів $\epsilon$ ïх неізольованість, зв'язаність 3 іншими 
подібними структурами знання. Концепти виникають та інтерпретуються «на фоні» інших структур знань, займаючи різні рівні в концептуальній організації концептосфери. Її семантичні фрагменти характеризуються різним ступенем узагальненості i знаходяться один 3 одним у класифікаційних відношеннях, які створюють ії неповторну структуру.

Будь-який концепт може висвітлюватись на тлі концептосфери, або іiі структурної одиниці - домену.

Сучасні лінгвісти досліджують мову в тісному зв'язку 3 людиною, що обумовлює необхідність лінгвістичного аналізу художнього тексту, як безпосереднього відображення свідомості людини, адже художній твір $є$ вираженням особистості автора, його ідей та їх мовного втілення.

Учені наголошують на тому, що аналіз художнього тексту дає змогу дослідити зміст окремих концептів та концептуальної картини світу, яка формується у свідомості людини під час пізнання, механізми перетворення культурного концепту, як стереотипу про певний фрагмент дійсності, у індивідуально-авторський - його суб' єктивне бачення людиною.

Концептуальний аналіз художніх текстів дає змогу отримати відомості про універсальні та ідіостильові характеристики мовної картини світу поета (письменника); у кожному конкретному тексті збагачені авторською інтерпретацією концепти реалізуються порізному, при цьому зберігаючи основне концептуальне ядро.

Як відомо, текст є взірцем складної мовної форми, складного семіотичного простору, що спонукають до творчого процесу його розуміння, сприйняття, інтерпретації, домислювання та когнітивної діяльності, яка пов'язана 3 осмисленням людського досвіду, зосередженого в концептах та матеріалізованого, перш за все, на лексичному рівні. Концепти, безпосередньо пов'язані зі збереженням та осмисленням різноманітної інформації, складають основу змістової структури тексту та пізнання навколишньої дійсності [5].

Змістові параметри семантики тексту дозволяють зробити висновок про те, що головними мотивами при створенні тексту $є$ намагання передати певний зміст, який у певних проявах можемо ототожнювати 3 поняттям інформації. Головна властивість інформації полягає у тому, що вона притаманна різним явищам, якісно при цьому відрізняючись. У лінгвістиці існує низка спроб визначити і класифікувати різні види текстової інформації. Наприклад, згідно 3 
класифікацією I. Гальперіна, існує змістово-фактуальна, змістовоконцептуальна та змістово-підтекстова інформація [4, с. 30-36].

Отже, одним 3 основних об'єктів сучасної когнітивної лінгвістики є вербалізований концепт. Увагу лінгвістів привертають перш за все основні, «базові», концепти, що найтісніше пов'язані 3 культурою народу i найяскравіше відбивають специфіку його колективної свідомості. Одним 3 них є концепт «чоловік».

Останнім часом спостерігаємо динамічне зростання кількості лінгвістичних робіт, присвячених вивченню цього концепту. Однак, всупереч значній кількості досліджень у галузі лінгвоконцептології, мовне вираження концепту «чоловік» у сучасній українській прозі вивчене недостатньо. Цим i зумовлена актуальність нашого дослідження: «Засоби мовного вираження концепту «чоловік» (за романом В. Шкляра «Залишенець» [11].

Автора цього роману називають батьком українського бестселера. Він $є$ переможцем літературної премії імені Тараса Шевченка 2010 року 3 романом «Залишенець. Чорний ворон». Первинна назва твору «Залишенець», тобто, той, хто до кінця залишився вірним девізу, написаному на чорному бойовому прапорі повстанців Холодного Яру «Воля України або смерть!». Саме під цією назвою роман здобув першу премію Ліги українських меценатів за кращий історичний роман. Потім з'явилась назва «Чорний ворон» за ім'ям псевдоголовного героя.

Відомий Василь Шкляр й іншими своїми творами: «Тінь сови», «Ностальгія», «Ключ», «Елементал», «Кров кажана» тощо. Василя Шкляра називають одним із найпопулярніших письменників, а ще «містичним» письменником. У нього чимало літературних премій. Проте найулюбленіша - «Автор, чиїх книжок найбільше викрали з магазинів».

Сьогодні серед письменників дуже популярною $є$ тема українських національно-визвольних змагань 40-50-х років під проводом ОУН-УПА.

В. Шкляр присвятив свій твір зображенню долі Чорного Ворона отамана банди партизан, які воювали проти радянської ради на території України в 30-х роках XX століття. Сюжет роману полягає в тому, що українські повстанці Холодного Яру борються проти більшовицької влади. На головний стрижень нанизано певну кількість епізодів, в основному пов'язаних із героїчними діями лісовиків: $y$ Капітанівці вони ще запалили волосний виконком, перед тим забравии в його голови «громадський податок» сто десять мільйонів совєтських рублів <...> По дорозі заодно підпалили ще комнезам, 
спровадивши його голову до небесної канщелярії ... (10, с.16) (Далі покликаємося на це видання, зазначаючи лише сторінку) тощо.

За містичність і загадковість твору відповідають чорний ворон (птах), що спостерігає за подіями і все розуміє, сліпа ворожка, загадкова дівчина, яка приходить на ніч до Чорного Ворона (людини), юродивий Варфоломій, що не гине, як не стараються «безбожні москалі».

Як відомо, авторське бачення дійсності втілюється в контексті тексту та пропагується читачам за допомогою категорії оцінки. Оцінне значення є істотним компонентом смислу тексту.

Отже, аналіз роману виявив негативне ставлення В. Шкляра до представників радянської ради. Так, на позначення чоловіків-більшовиків письменник використовує синонімічний ряд 3 пейоративним забарвленням: кацап'юга, вилупок, кащапидло, приходень, заброда, бебех, нахаба, йолоп, голодранець, ледаџюга, крикун, босота, шельма, навіжений, десятихатник, орел губчека, покруч, головоріз, нетяга, катюга, виродок, здохляк, роззява, безбожник, драпіжник, курдупель, нелюдь, жмикрут, самозванець, горлоріз, каратель, перевертень. Наприклад: - Невже ви нас г-гастгєляєтє? - із тремтячим подивом запитав Сєня <...> Ви могли б нас обміняти. - Ну ти, міняйло! - дулом револьвера Коляда штовхнув його між лопатки. - Ти шо, Дзіржінський чи шо! За тебе не дадуть і собачого хвоста ... (51).

До членів партизанських загонів і міліціонерів автор відчуває симпатію, співпереживає ним, що підтверджує використання вербалізаторів 3 традиційним мейоративним забарвленням: голуб, бідолаха, чоловічок, сокіл, сміливець, хом'ячок і нейтральним: бородань, рябий, хлопчисько, хлопчина. Наприклад: Другий мілічіонер зішулився, сидів $i$ не дихав, - його маленьке личко було надуте, мов у того хом'ячка, щуо за кожною щокою приховав по жмені пшениці (83).

У романі є вербалізатори концепту «чоловік», які традиційно мають негативне забарвлення, а у творі їх використано 3 мейоративним забарвленням: неборака, розумака, чудак, шибайголова, одчайдух, здоровило, блукалець, чолов'яга.

Одним із лінгвістичних ресурсів мовної репрезентації концепту в творі є художня образність, за допомогою якої автор показує певні якості, характерні риси чоловіка. Розуміння тропів як сутності творчого мислення, способу пізнання світу, основи образності формувалося в тривалому розвиткові поетології, починаючи від учення Аристотеля про поетичне мистецтво.

() О. В. Архіпова, 2012.

$-114-$ 
Величезне значення для глибинного усвідомлення тропів мала теорія словесності О. Потебні та його послідовників. Фіксація віддзеркалення тропами гетерогенності людської свідомості дала ученим вагомі підстави включати їх в основу типологізації культури.

Вербалізаторами концепту «чоловік» у романі В. Шкляра «Залишенець» $є$ такі художні засоби, як епітети, порівняння, метафори.

Під «епітетом» розуміємо текстове утворення обов'язкової двохкомпонентної структури, до складу якої на паритетних засадах входять означення та означуване. Це дуже жорстке архітектонічне та семантичне утворення варто іменувати епітетною структурою. Виникнення епітетної структури не завжди відбувається свідомо для автора. У більшості випадків залишається певний простір для сумнівів: наскільки свідомо контролюється процес (механізм) остаточного поєднання означення та означуваного в епітетну структуру. Формування, модифікація та накопичення епітетних структур призводить до утворення епітетних систем. Епітетні системи формуються в межах усієї творчості письменника (стилю), у межах літературних напрямів, течій, шкіл (груп), національних літератур, історичних епох і в масштабах всесвітньої літератури [2, с. 29-35].

Одним із часто вживаних тропів-вербалізаторів концепту «чоловік» у романі є порівняння - зображення особи, предмета, явища чи дії через найхарактерніші ознаки, які є органічно властивими іншим. Художні порівняння поділяють на два типи: помірно експресивні, які сприймаються без інтелектуального напруження i дуже експресивні, котрі потребують асоціативної розумової активізації людини. У «Залишенці» В. Шкляра є обидва типи порівнянь.

Втім, найдієвішим засобом естетизації художнього мовлення $\mathrm{i}$ вербалізації концепту є метафора - семантичний процес, при якому форма мовної одиниці або оформлення мовної категорії переноситься 3 одного об'єкта позначення на інший на основі певної подібності між цими об' єктами при відображені у свідомості мовця [9, с. 221-224].

Найбільш часто в досліджуваному творі вербалізаторами концепту «чоловік» $є$ епітети й порівняння, метафори виконують цю функцію рідше.

У романі цей концепт розкрито за допомогою епітетів, порівнянь, метафор, які мають різне забарвлення i описують внутрішні й зовнішні характеристики чоловіка.

Концептуальний аспект «зовнішність» представлено вербалізаторами з пейоративним забарвленням: 
- епітетами: закандзюблений ніс, вислозадий командир, широко ошкірений, хижсии рот, провалені, лискучі, зизі, скляні очі, діжкуватий, зімулений, сухоребрий, шмаркатий, великоголовий, голомозий, червонопикий, вирлоокий, вухатий москаль. Наприклад: Високий приходень у шкірянці з тонкою гусячою шиєю, обсипаною прищами ... (17); ... кіннотники у рогатих шапках будьонівках з величезними ганчір'яними зірками на лобі ... (20).

- порівняннями: ноги колесом; чорні ипарини очей; великі, мов курячі яйя, баньки; схожий на сову чоловік; навіжений з вовчим оскалом; кругла, як кавун, довбешка; маленькі пташині очі; висушене, як у мумії, обличчя; худий, як драбина; гострі, як сучки, кулаки; лище червоне, як мідний казан. Як-от: А лівобіч крутив на всі боки качиною головою начальник ревкому Долбоносов. У нього й справді був ніс-долото, плескатий і довгий, як у качура...(47); Напрочуд зворушливий вигляд мали голомозі москалики <...>, ну геть тобі діти, вони гули, як жуки, але так натхненно, що можна було заридати від цьього видовища... (51).

Метафори на позначення рис зовнішності партизанів мають мейоративне забарвлення: Отаман трішки спохмурнів, та потім загадкова усмішка заграла в його закручених вусах... (36); О, то була ще та делегаџія! 〈...> $\boldsymbol{я}$ зі своєю зарослою фізіономією $і$ гривою до плечей, у польовій блідо-зеленій формі та кавалерійських чоботях...(103); ...очі його сміялися навіть у гніві... (121).

3 негативним забарвленням в романі використано метафору на позначення рис зовнішності командира-червоноармійця: Miласті просім! увернув довгобразий Кузякін, сяючи поголеним черепом... (104).

Для опису зовнішності чоловіків-партизан В. Шкляр поєднує епітет 3 порівнянням: Чикирда зачудовано дивився на Ходю волохатими, як джмелі, очима (108).

Серед епітетів-вербалізаторів концепту «чоловік» на позначення внутрішніх характеристик можна виокремити такі концептуальні аспекти: розумові здібності, фізичний та емоційний стан, характер.

Концептуальний аспект: «розумові здібності» представлено епітетами:

- 3 пейоративним забарвленням: твердоголовий, юродивий, здуряний. Наприклад: Митрюха Гєрасімов не витримав, ударив мертвого чоботом, тоді вихопив у когось гвинтівку $і$ кольбою став гамселити в усміхнене, нестерпно красиве лище. Його орда сприйняла цุю лють як наказ, кацап'юги юрбою налетіли на мертвого - дрібні, кривоногі, але дуже мордаті, $з$ пласкими, налитими кров'ю () О. В. Архіпова, 2012. 
мармизами, - вони з дикунським гелготанням $і$ матючнею також почали гамселити отамана кольбами(13);

- з мейоративним забарвленням: одукований, грамотний.

Концептуальний аспект: «фізичний стан» письменник розкриває за допомогою порівняння з мейоративним забарвленням: здоровий, як бик: ... як марафонець, що з останніх сил доніс радісну звістку до місця призначення, він мертвий упав головою на стіл $i$ захріп (64) й метафори: Дереза $і$ тут не опинався, лише коли залізний шатун занурив у воду його голову, він засмикався усім тілом (100).

Емоційний стан партизанів змальовано епітетами: скам'янілий, спантеличений, очманілий, набурмосений, заломлений, зневірений, огламенний, настовбурчений, набичений, приголомшений. Наприклад: - Да как ви смєєтє? - верескнув Яша Гальперович, і його бурякове від злості лице раптом взялося крейдою... (21); Головний черкаський «бебех» подивився на мене 3 псячою відданістю...(22); Козаки, виморені роками боротьби, змучені лісовим життям ...(24).

Пейоративне забарвлення мають порівняння на позначення емоційного стану як партизанів, так і більшовиків: Затинався, немов контужений...(25); Я його випхав з нашого табору, як паршиву вівцю...(42); ...походжав, як півень...(6); Зажуриться чоловік, ходить, як припутень, не їсть, не n'є, світ йому не милий...(24), Надутий, як сич... (92). Це можна пояснити довготривалістю воєнної кампанії: знесиленими війною були як партизани, так і більшовики.

Концептуальний аспект «емоційний стан» чоловіка розкриває поєднання тропів:

- метафора + порівняння: А халат я побачив на ньому пізніше, коли Ходя, сяючи, як нова копійка, приміряв його на себе вже в таборі (103);

- епітет + порівняння: ... лице, схоже на страхітливу маску ощцрене, з червоними голими повіками і лисими бровами...(46).

Характер партизан розкрито епітетами: суворий командирський голос, хрипкувато-солодкий голос, густий баритон, тонкосльозий, вертлявий, добросердий, нахрапистий.

Пейоративне забарвлення має метафора, яка описує негативні риси характеру партизан: Василь Чучупака, - терпіти не міг балакунів, котрі мали язики довщі за шаблю...(40).

Однією 3 особливостей мовного стилю В. Шкляра $\epsilon$ нагромадження тропів-вербалізаторів концепту «чоловік», так у романі «Залишенець» поєднано опис зовнішніх і внутрішніх рис 
чоловіка, а саме зовнішності й емоційного стану.

Вербалізаторами досліджуваного концептуального аспекту є:

- епітети: ...всі як один були перевдягнуті в будьонівське манаття, а Вовкулака їхав попереду ще й з червоним прапором. Треба було бачити цю самовдоволену пику з вишкіреними зубами ...(43);

- епітет + метафора + гіпербола: Були то невеличкі на зріст, карячконогі, пихаті й нахраписті москалі, довготелесі, товстошкурі латиші з крижсаними очима, вовкуваті й вічно голодні китайщі, яких наші селяни називали «сліпими», юродиві з лиця чуваші та башкири...(20);

- епітет + порівняння: Скрипаль у чорному фраку з білим нагрудником і довгими, схожими на пташиний хвіст фалдами, скидався на печальну сороку, $і$ ияя несусвітня сорока, окільцьована пейсами, не грала, а малювала смичком якийсь позахмарний світ - 3 медовими ріками й иукровими снігами (44).

Аналіз художніх засобів, які вербалізують концепт «чоловік» у романі В. Шкляра «Залишенець» свідчить про те, що в індивідуально-авторській репрезентації цього концепту домінують епітети, метафори й порівняння, які означують негативні риси більшовиків і позитивні риси партизан. Це пояснюється ідейною спрямованістю твору - автор звинувачує більшовиків, котрі виступали проти визнання незалежності України в 30-х роках XX століття і возвеличує партизанів, які боролися за визнання суверенітету УНР.

Перспективи дослідження вбачаємо у вивченні мовної репрезентації концепту «чоловік» на зіставленні центральних вербалізаторів у творах сучасної української жіночої та чоловічої прози.

\section{Література}

1. Бондаренко О. С. Концепти «чоловік» і «жінка» в українській та англійській мовних картинах світу : [автореферат дисертації на здобуття наукового ступеня кандидата філологічних наук] / О. С. Бондаренко. - Донецьк, 2005. - 20 с.

2. Волковинський О. І. Поетика епітета: пролегомени до теми / О. І. Волковинський // Біблія і культура, 2009. - № 11. - С. 29-33.

3. Воркачев С. Г. Методологические основания лингвоконцептологии / С. Г. Воркачев // Теоретическая и прикладная лингвистика. - Воронеж, 2002. - Вып. 3. - С. 79-95.

4. Гальперин И. Р. Текст как объект лингвистического исследования / И. Р. Гальперин. - М. : Наука, 1981. - 138 с.

5. Мельничук О. Д. Концепти як елементи семантики тексту [Електронний peсурс] / О. Д. Мельничук. - Режим доступу : http://studentam.net.ua/content/view/8783/97.

6. Пода О. М. Історія українського жіночого журналу: специфіка міждисциплінарного підходу [Електронний ресурс] / О. М. Пода. - Режим доступу : http://vuzlib.com/content/view/1582/43.

() О. В. Архіпова, 2012. 
7. Потапенко С. I. Мовна особистість у просторі медійного дискурсу (досвід лінгвокогнітивного аналізу) / С. І. Потапенко. - К. : Вид. центр КНЛУ, 2004. - 360 с.

8. Степанов Ю. С. Константы. Словарь русской культуры. Опыт исследования / Ю. С. Степанов. - М., 1997. - 724 с.

9. Чабаненко В. А. Стилістика експресивних засобів української мови: [монографія] / В. А. Чабаненко. - Запоріжжя : ЗДУ, 2002. - 167 с.

10. Шкляр В. Залишенець / В. Шкляр. - Харків : Книжковий Клуб «Клуб Сімейного Дозвілля», 2010. - 384 с.

Стаття надійшла до редакції 11.10.2012 p. 